\title{
Prevalence of Chronic Kidney Disease in Asia: A Systematic Review of Population-Based Studies
}

\author{
Yusra Habib Khan1, Tauqeer Hussain Mallhi22, Azmi Sarriff3, Amer Hayat Khan³ and Nida Tanveer4
}

\begin{abstract}
Chronic kidney disease (CKD) is an asymptomatic disease associated with high morbidity and life-threatening complications that lead to decreased life expectancy. Worldwide prevalence of CKD is escalating at an alarming rate. Large population-based representative surveys have been reported in Western countries to estimate the prevalence of the disease. However, there is paucity of data as far as developing nations are concerned. Asia is the world's largest continent accommodating maximum number of under-developed and developing countries with an unclear picture of prevalence of CKD. Current review attempts to give an insight to the prevalence of CKD in this region by combining population-based surveys. This review will assist in estimating the burden of CKD in Asia, so that appropriate control measures could be designed.
\end{abstract}

Key Words: Prevalence, Chronic kidney disease, Asia, Cockroft-Gault formula, MDRD formula, Renal function equations.

\section{INTRODUCTION}

Chronic kidney disease (CKD) is a general term that is used to describe a number of medical complications effecting morphological structure and physiological function of the kidney. The disease progresses slowly over months or even years and symptoms do not appear until kidney function becomes one-tenth of normal or kidney failure is imminent. ${ }^{1}$ Being asymptomatic, the disease manifests itself with a variety of non-specific symptoms. Due to silent progressive nature of disease, its diagnosis remains neglected until it reaches endstage renal disease (ESRD), where routine dialysis or kidney transplantation is the only cure for survival. It is well-documented that ESRD is associated with increased mortality, decreased patient quality of life and extremely high risk of comorbidities such as hypertension, diabetic nephropathy, anemia and cardiovascular complications. ${ }^{2}$ Early detection of CKD is crucial as both pharmacological and non-pharmacological interventions are likely to be less effective if disease progresses to advanced stages.3,4 Moreover, early detection of disease helps to prevent or at least delay disease progression and to reduce associated

${ }^{1}$ Institute of Pharmacy, Lahore College for Women University, Lahore, Pakistan

2 Department of Pharmacy Practice, Faculty of Pharmaceutical Sciences, Government College University Faisalabad, Faisalabad-38000, Pakistan

3 Discipline of Clinical Pharmacy, School of Pharmaceutical Sciences, Universiti Sains Malaysia, Penang 11800, Malaysia

4 Allied Hospital, Punjab Medical College, Faisalabad-38000, Pakistan

Correspondence: Dr. Yusra Habib Khan, Institute of Pharmacy, Lahore College for Women University, Lahore, Pakistan

E-mail: yusrahabib@ymail.com

Received: January 19, 2018; Accepted: September 27, 2018 complications. According to American Heart Association (AHA), CKD is an independent and most crucial risk factor for subsequent cardiovascular complications. 2,5

Currently, CKD is affecting $10-16 \%$ of adult population around the globe. Worldwide prevalence of disease is escalating with kidney diseases being 9th leading cause of death in United States causing total expenditure of more than 47.5 billion dollars in 2010.6,7 Annually, there are more than 100 million deaths due to lack of provision of renal replacement therapy (RRT) as a result of ESRD. The prevalence of CKD in Asia varies from 10-18\%, which is not much different from other parts of the world. However, due to paucity of data in most Asian countries, the exact burden and cost associated with disease is still not clear. ${ }^{8}$ Due to the limited availability of resources, particularly in Asia, where most of the countries are still underdeveloped or developing, the increased prevalence of disease puts a large burden on healthcare systems and affects patients' quality of life.

Assessment of kidney function, i.e. glomerular filtration rate (GFR) is extremely crucial for the diagnosis and staging of kidney disease. ${ }^{1}$ Moreover, many clinical procedures and predictive equations are also being used to assess renal function and to determine the extent of kidney dysfunction.9,10 However, National Kidney Foundation (NKF) recommends the use of renal function predictive equations to assess eGFR rather than direct measurement of GFR. ${ }^{11,12}$

The current review aims to shed light on the prevalence of CKD in Asian countries by reviewing relevant populationbased research studies on prevalence of CKD using renal function predictive equations among Asian populations.

\section{METHODOLOGY}

A systematic literature review was conducted to find out relevant studies (research and review articles) since 
2000. PubMed database, Google Scholar, and Ebscohost were used to identify potential publications. The search strategies were designed with the help of librarian; and two researchers independently reviewed and discussed relevant publications. Cross-references were also checked to identify further related publications. Following keywords were used to retrieve data: Asia, chronic renal/ kidney disease, Cockroft-Gault formula, glomerular filtration rate, GFR, MDRD equation, prevalence, renal/kidney disease, respective names of Asians countries.

Inclusion criteria: A prospective protocol was designed by researchers for selection of studies explaining prevalence of CKD among Asian population. Studies were eligible to be included when they met following criteria: conducted among representative sample of general population; CKD was defined as creatinine clearance $\mathrm{CrCl}$ or GFR $>60 \mathrm{ml} / \mathrm{min} / 1.73 \mathrm{~m}^{2}$; and use of renal function predictive equation to calculate eGFR: Cockroft-Gault equation, MDRD equation (standardized for BSA i.e. body surface area), CKD-EPI equation included CG formula: creatinine clearance $(\mathrm{ml} / \mathrm{min})=$ $\{(140-$ age $)$ *serum creatinine* body weight $(\mathrm{kg})\} / 72$ * (0.85 if patient is female); MDRD equation: GFR $/ \mathrm{ml} / \mathrm{min} / 1.73 \mathrm{~m}^{2}=186$ * (serum creatinine)-1.154 *(age) -0.023 * (0.742 if patient is female); and CKD-EPI equation: eGFR $=141^{*}$ min (serum creatinine $\left./ k, 1\right) a$ * $\max (\text { serum creatinine/k,1) })^{-1.209 *} 0.993$ age * $[1.018$ if female] * [1.159 if Black], where $k$ is 0.7 for females and 0.9 for males, $a$ is -0.329 for females and -0.411 for males, min indicates the minimum, max indicates the maximum.

Exclusion criteria: Studies were not included in this review if they met any of following criteria: sample size of less than 100; language other than English; estimation of GFR by methods other than renal function predictive equations, full text is not available; and case control studies and meta-analyses.

Validity of selected data: Factors that can influence validity of studies were carefully studied and noted. In order to avoid repetition of data, multiple publications on the same topic, and same authors or group of authors were separated. These multiple publications were then screened individually and compared with each other before final inclusion of any study in this review.

Data extracted: The information extracted from each study for this review included study design, characteristics of study participants, sample size, duration and method used to estimate prevalence, and overall prevalence of CKD among investigated population.

Definition of kidney function: Renal function predictive equations based on serum creatinine, age, weight and/or race were used to determine kidney function. Here CKD was defined on the basis of definition published by NKF: Creatinine clearance or GFR less than $60 \mathrm{ml} / \mathrm{min} / 1.73 \mathrm{~m}^{2}$ where $1.73 \mathrm{~m}^{2}$ is the value for body surface area (BSA). All the studies included in this review expressed serum creatinine in $\mathrm{mg} / \mathrm{dl}$, weight in $\mathrm{kg}$, age in years, and GFR on $\mathrm{ml} / \mathrm{min} / 1.73 \mathrm{~m}^{2} .{ }^{12}$

\section{RESULTS}

Literature search was undertaken to retrieve publications of potential interest. Initially, 93 publications were retrieved, of which 50 were excluded due to failure to fulfill the inclusion criteria. As a result of initial screening, 43 selected publications were subjected to detailed evaluation and 25 studies corresponding to the inclusion criteria were included in the review (Figure 1).

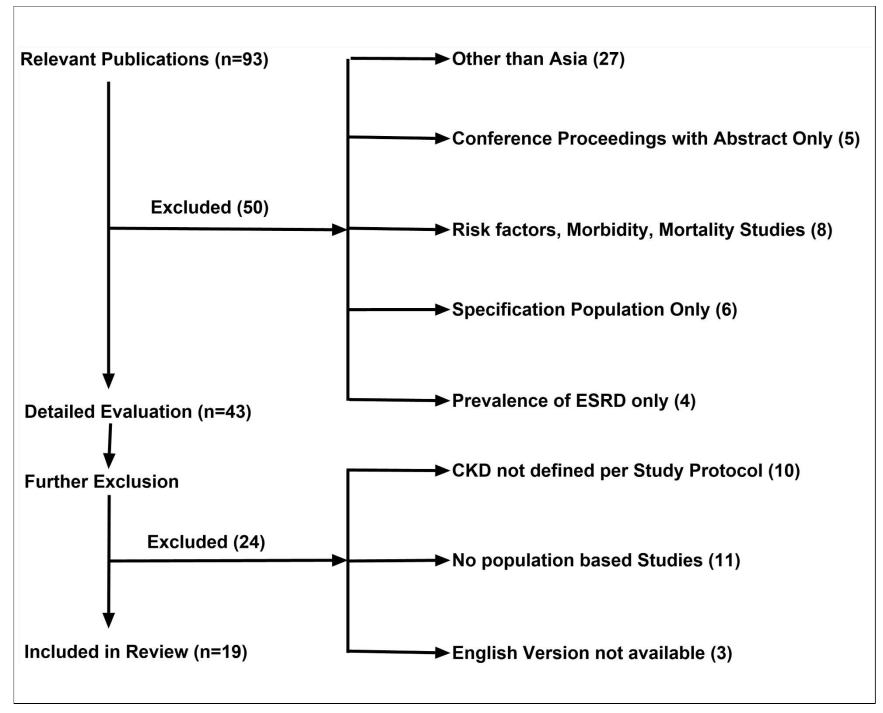

Figure 1: Flowchart summarising literature review.

General characteristics: All the studies included in this review are summarised according to location of respective country in different regions of Asia (Table I). Out of 25 studies included in the current review, seven studies were from South Asia, seven from East Asia, three from West Asia, and eight studies were from South-East Asia. Unfortunately, we did not come across any study from Central Asian regions including Tajikistan, Turkmenistan and Afghanistan.

Out of 25 extracted studies, 20 studies were crosssectional, while 5 studies used cohort study design. ${ }^{13-17}$ Out of 20 studies using cross-sectional data in this review, two studies included data from respective National Health Surveys, ${ }^{15,18}$ out of which one study has used data from National Health and Nutrition Examination Survey but with four different time periods i.e. 1998, 2001, 2005, 2009,15 while Hooi et al. took data from National Health and Morbidity Survey. ${ }^{18}$ The number of participants ranged from 293 to $33,276,15,19$ except for one study, all the participants had age $\geq 18$ years. ${ }^{20}$

Renal function predictive equations and prevalence of CKD: Overall, the prevalence of CKD was assessed via MDRD equation in most studies followed by CKD- 
Table I: Prevalence of chronic kidney disease in Asia according to population-based studies.

\begin{tabular}{|c|c|c|c|c|}
\hline Authors & Country & Study design, No. of participants & Participants' characteristics & Overall prevalence of CKD \\
\hline Varma et al. $2010^{21}$ & India (South Asia) & Cross sectional survey, $n=3398$ & $66 \%$ male, age above 18 years & $3.02 \%$ with MDRD formula \\
\hline Singh et al. $2013^{13}$ & India (South Asia) & Prospective cohort study, $n=5588$ & $55 \%$ male, age range of $18-98$ years & $5.09 \%$ with MDRD formula \\
\hline Huda et al. 201220 & Bangladesh (South Asia) & Cross sectional survey, $n=1000$ & $33 \%$ male, age range of $15-65$ years & $\begin{array}{l}13.1 \% \text { with MDRD } 16 \% \\
\text { with CG formula }\end{array}$ \\
\hline Anand et al. 201422 & Bangladesh (South Asia) & Cross-sectional survey, $\mathrm{n}=357$ & $51 \%$ men with age $>30$ years & $26 \%$ with CKD-EPI \\
\hline Jessani et al. $2014^{23}$ & Pakistan (South Asia) & Cross-sectional survey $n=2873$ & $52.2 \%$ female, Age 40 years and above & $12.5 \%$ with CKD-EPI formula \\
\hline Imran et al. $2015^{19}$ & Pakistan (South Asia) & $\begin{array}{l}\text { Cross-sectional survey by arranging } \\
\text { health campus } n=293\end{array}$ & $64.5 \%$ male, age 30 years and above & $25 \%$ with CKD-EPI formula \\
\hline Sharma et al. $2013^{24}$ & Nepal (South Asia) & $\begin{array}{l}\text { Community-based screening with } \\
\text { proportionate stratification, } n=1000\end{array}$ & $\begin{array}{l}48 \% \text { male, } 52 \% \text { female with age range } \\
\text { of } 20-60 \text { years }\end{array}$ & $6.3 \%$ with MDRD \\
\hline Chen et al. $2005^{25}$ & China (East Asia) & $\begin{array}{l}\text { Cross-sectional survey with random } \\
\text { sampling, } n=15540\end{array}$ & $\begin{array}{l}48 \% \text { male, } 52 \% \text { female with age range } \\
\text { of } 35-74 \text { years }\end{array}$ & $2.5 \%$ with MDRD equation \\
\hline Li et al. $2006^{26}$ & China (East Asia) & $\begin{array}{l}\text { Community based cross-sectional } \\
\text { survey, } n=2310\end{array}$ & $\begin{array}{l}49 \% \text { male, } 51 \% \text { female with age } \\
40 \text { years and above }\end{array}$ & $4.9 \%$ with MDRD equation \\
\hline Zhang et al. $2008^{27}$ & China (East Asia) & $\begin{array}{l}\text { Cross-sectional survey with systematic } \\
\text { sampling, } n=13,925\end{array}$ & $\begin{array}{l}\text { Male to female ratio } 1: 18: 1 \text { with } \\
\text { age range of } 18 \text { - less than } 70 \text { years }\end{array}$ & $13 \%$ with MDRD equation \\
\hline Ninomiya et al. 200514 & Japan (East Asia) & Prospective cohort study, $n=2634$ & $\begin{array}{l}42 \% \text { male, } 58 \% \text { female with age } \\
40 \text { years and above }\end{array}$ & $10.3 \%$ with MDRD equation \\
\hline Konta et al. $2006^{28}$ & Japan (East Asia) & Cross-sectional survey, n2321 & $\begin{array}{l}44 \% \text { male, } 56 \% \text { female with age above } \\
40 \text { years }\end{array}$ & $28.8 \%$ with $C G$ equation \\
\hline Yi et al. $2010^{29}$ & Mongolia (East Asia) & Cross-sectional survey, $n=4522$ & $\begin{array}{l}50 \% \text { male, } 50 \% \text { female with mean age } \\
\text { of } 50.3+14.3 \text { years }\end{array}$ & $12.95 \%$ with MDRD equation \\
\hline Kang et al. $2013^{15}$ & Korea (East Asia) & $\begin{array}{l}\text { Prospective cohort survey (KNHANES) } \\
\text { with sampling weight method, } \\
n=33276\end{array}$ & $\begin{array}{l}43 \% \text { men, } 57 \% \text { female with age above } \\
20 \text { years }\end{array}$ & $\begin{array}{l}\text { With MDRD equation } \\
\text { 1998: } 10.3 \% \\
\text { 2001: } 18.2 \% \\
\text { 2005: } 17.4 \% \\
\text { 2009: } 10.8 \%\end{array}$ \\
\hline $\begin{array}{l}\text { Hosseinpanah et al. } \\
200916\end{array}$ & Iran (West Asia) & $\begin{array}{l}\text { Cross-sectional study with TLGS cohort, } \\
n=10063\end{array}$ & $\begin{array}{l}42 \% \text { male, } 58 \% \text { female with age over } \\
20 \text { years }\end{array}$ & $\begin{array}{l}18.9 \% \text { with MDRD } \\
\text { equation }\end{array}$ \\
\hline Sahin et al. 200930 & Turkey (West Asia) & Cross-sectional study, $\mathrm{n}=1079$ & $\begin{array}{l}49 \% \text { male, } 51 \% \text { female with age range } \\
\text { of } 18 \text { to } 95 \text { years }\end{array}$ & $5.75 \%$ with MDRD equation \\
\hline Alsuwaida et al. $2010^{31}$ & Saudi Arabia (West Asia) & Pilot community based screening, $n=491$ & $\begin{array}{l}50 \% \text { male, } 50 \% \text { female with mean age } \\
\text { of } 37.4+1.3\end{array}$ & $\begin{array}{l}5.7 \% \text { with MDRD } \\
5.3 \% \text { with CG equation }\end{array}$ \\
\hline Perkovic et al. 200732 & Thailand (South-East Asia) & $\begin{array}{l}\text { Cross-sectional survey with stratified } \\
\text { cluster sampling, } n=5146\end{array}$ & $49 \%$ male, age range of $35-$ over 65 & $\begin{array}{l}13.81 \% \text { with MDRD } \\
21.04 \% \text { with CG equation }\end{array}$ \\
\hline $\begin{array}{l}\text { Domrongkitchaiporn et al. } \\
2005^{33}\end{array}$ & Thailand (South-East Asia) & Cross-sectional study $n=2967$ & $76 \%$ male age range of $35-55$ years & $6.8 \%$ with MDRD equation \\
\hline Shankar et al. $2008^{34}$ & Singapore (South-East Asia) & $\begin{array}{l}\text { Cross-sectional survey with local } \\
\text { Malay adults } n=2783\end{array}$ & $\begin{array}{l}47 \% \text { male, } 53 \% \text { female with age range } \\
\text { of } 49-80 \text { years }\end{array}$ & $20.4 \%$ with MDRD equation \\
\hline $\begin{array}{l}\text { Sabanayagam et al. } \\
2010^{35}\end{array}$ & Singapore (South East Asia) & Cross-sectional survey, $\mathrm{n}=4499$ & $\begin{array}{l}48 \% \text { male, } 52 \% \text { female with age range } \\
\text { of } 24-95 \text { years }\end{array}$ & $5.5 \%$ with MDRD equation \\
\hline $\begin{array}{l}\text { Prodjosudjadi et al. } \\
2009^{36}\end{array}$ & Indonesia (South-East Asia) & $\begin{array}{l}\text { Community-based prospective } \\
\text { survey, } n=9412\end{array}$ & $36 \%$ male, $64 \%$ female & $\begin{array}{l}12.5 \% \text { with CG } \\
8.6 \% \text { with MDRD }\end{array}$ \\
\hline Tennille et al. 201317 & Philippines (South-East Asia) & $\begin{array}{l}\text { Cohort survey (NNHeS) with stratified } \\
\text { multi-stage cluster sampling, } n=7702\end{array}$ & With age range of $20-70$ years & $6.7 \%$ with CKD-EPI formula \\
\hline Ito et al. $2008^{37}$ & Vietnam (South-East Asia) & $\begin{array}{l}\text { Prospective community-based survey } \\
\text { with random sampling, } n=8504\end{array}$ & $\begin{array}{l}35 \% \text { male, } 75 \% \text { female with age } 40 \\
\text { years and above }\end{array}$ & $\begin{array}{l}3.1 \% \text { with CG } \\
3.6 \% \text { with MDRD adjusted } \\
\text { with Japanese co-efficent }\end{array}$ \\
\hline Hooi et al. $2013^{18}$ & $\begin{array}{l}\text { West Malaysia } \\
\text { (South-East Asia) }\end{array}$ & $\begin{array}{l}876 \text { individuals from the National } \\
\text { Health and Morbidity Survey }\end{array}$ & Adult (18 years and above) & 9.07 with CKD-EPI formula \\
\hline
\end{tabular}

EPI equation while only two studies used CG equation. ${ }^{17,28}$ Five studies used both MDRD and CG equation. $20,31,32,36,37$ Studies that used both MDRD and CG equation, the prevalence of CKD was notably higher with CG equation as compared to MDRD equation. Study conducted by Ninomiya et al. reported prevalence of CKD in Japan as $10.3 \%$ with MDRD equation while one year later another study conducted elsewhere in Japan reported prevalence of CKD as $28.8 \%$ with CG equation. ${ }^{14,28}$ Both these studies were conducted with participants above 40 years and with almost similar sample size, i.e. 2,634 versus 2,321. The much higher reported difference in prevalence of CKD in similar population belonging to same geographical area leads to confusing results. Although we cannot compare both studies directly because both studies used different set of population as participants but still as the characteristics of population matches; therefore, such remarkable difference of $18.5 \%$ seems unacceptable.

Age and prevalence of CKD: Nine studies included in this review assessed prevalence of CKD with respect to participants' age.13,15,16,21,24-27,32,34,36 In general, prevalence of CKD increased with age within same study population. For instance, the prevalence of CKD from the fourth Korean National Health and Nutrition Examination Survey (KNHANES), a prospective cohort survey representing general population of Korea, increased from $2 \%$ to $12.7 \%$ from age group $20-39$ years to above 60 years. 15 Trends in prevalence of CKD with respect to age are shown in Figure 2. 


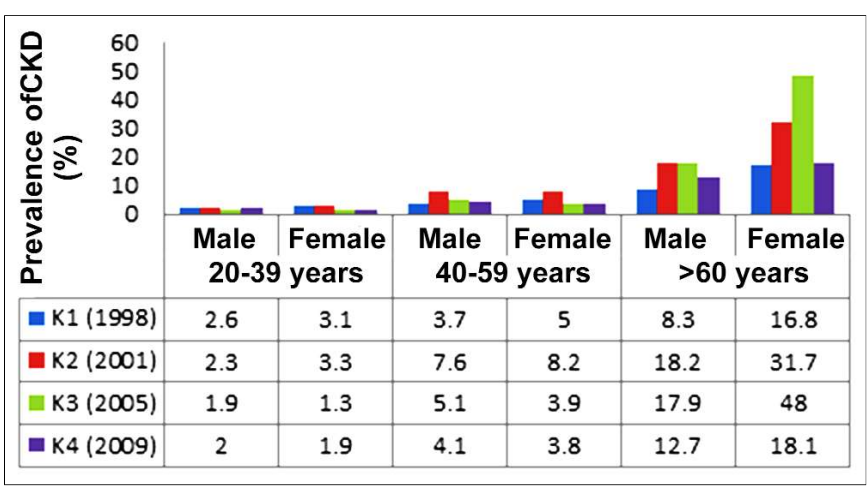

Figure 2: Trends in prevalence of CKD with respect to age in KNHANES.

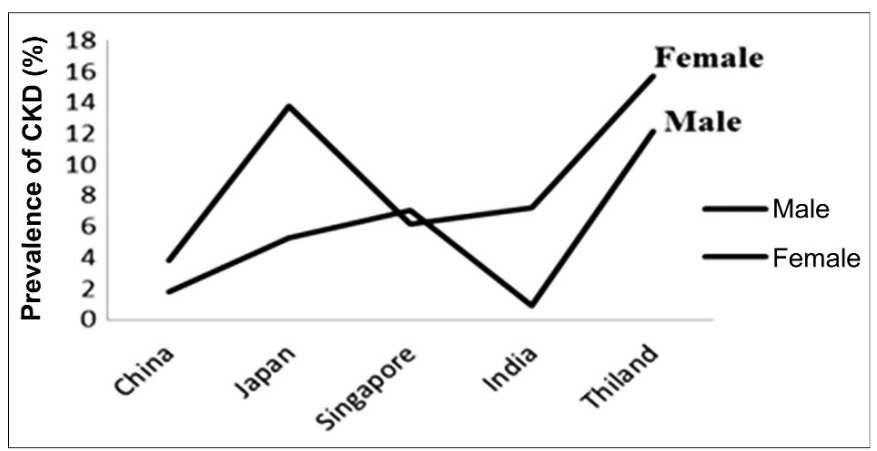

Figure 3: Trends in prevalence of CKD with respect to gender.

Gender and prevalence of CKD: CKD was more prevalent among women as compared to men. Higher prevalence of CKD among women was reported in all studies that had presented gender-specific prevalence of disease.15,16,21,25,26,32,36 Varma et al. reported remarkably higher prevalence of CKD among women as compared to men $(7.23 \%$ versus $0.94 \%) .{ }^{21}$ Gender specific prevalence of CKD among different studies of this review is shown in Figure 3.

Geographical location and prevalence of CKD: Asia is the largest and the most populous continent of the world. The studies included in this review belonged to four different geographical locations in Asia. Based on the use of renal function predictive equation, highest prevalence of CKD was observed in Japan (28.8\%) and Bangladesh (20.8\%) by CG and CKD-EPI equation respectively.22,28 On the other hand, lowest prevalence of CKD was reported in Vietnam (3.1\%) and India (3.02\%) with CG and MDRD equation respectively. ${ }^{21,37}$

\section{DISCUSSION}

Current systematic review attempts to summarise prevalence of CKD in Asia by including populationbased research studies in Asia that used renal function predictive equation and standardised definition of CKD. In general, the prevalence of CKD increased with age and was more prevalent among females. Moreover, the predicted prevalence of CKD was much higher with CG equation as compared to MDRD equation. As far as accuracy of renal function predictive equations is concerned, it is still a controversial issue. Most studies prefer MDRD over CG equation, while some studies still prefer CG equation. However, as both equations were derived from population cohort already having CKD; therefore, these equations tend to underestimate or overestimate kidney function in individuals with normal or slightly decreased kidney function. Furthermore, both equations use serum creatinine value for calculation of GFR that itself is the biggest limitation since creatinine production is effected by diet, diseases as well as certain pharmacological therapies. ${ }^{38,39}$ Based on NKF-KDOQI guidelines, the use of CKD-EPI equation is recommended for estimation of GFR. As compared to MDRD equation, CKD-EPI offers better sensitivity below eGFR $<60 \mathrm{ml} / \mathrm{min} / 1.73 \mathrm{~m}^{2}$ and same accuracy and sensitivity as MDRD equation for eGFR $>60 \mathrm{ml} / \mathrm{min} / 1.73 \mathrm{~m}^{2}$. Majority of the studies in current review have used MDRD equation to estimate prevalence of CKD, as MDRD equation was developed in 1999, while CKD-EPI equation was developed almost after a decade in 2009, and was adapted for use in clinical practice later.

Results of current review showed that regardless of the renal function predictive equation used and cohort under observation, prevalence of CKD increases with age. Similar results were documented in other globally (U.S, Europe) conducted studies.40,41 O'Hare et al. reported the age specific incidence of death and ESRD over a follow-up of 3 years. A total of 9,227 (4.4\%) patients developed ESRD, 45,772 (21.8\%) patients died before ESRD and 2,925 (1.4\%) died after initiating ESRD. Irrespective of baseline eGFR, authors reported a higher risk of death with old age with almost triple risk of death with age $>65$ years as compared to age $<45$ years and lowest risk of ESRD with young age with almost double risk of ESRD with age $<45$ years as compared to age $>65$ years. ${ }^{42}$ In a longitudinal observational study, 3,047 patients with CKD stage 3 were followed-up for 10 years to investigate prognosis of CKD. A total of $959(31 \%)$ patients died and $62(2 \%)$ died at the end of observation period. Authors reported that a 10 year increment in age is associated with $2.28 \mathrm{HR}(p<0.001)$ of death while a 0.75 HR ( $p$-value: 0.0009 ) of incident ESRD. 43 Similar results have been reported by a retrospective analysis of large sample of multi-ethnic (White, South-Asians, Black, others) population. 44 It is a well-documented fact that, regardless of gender, glomerular filtration rate (GFR) decreases $1 \mathrm{ml} / \mathrm{min} / 1.73 \mathrm{~m}^{2}$ in all healthy individuals after 30 years of age.45,46 Decline in kidney function might also be attributed to structural changes in kidney as a result of aging and presence of comorbidities. Moreover, the risk of developing CKD increases with advance age because other risk factors (hypertension, diabetes) for kidney disease are more prevalent in old people. Ageing is a non-regulatory risk factor for development of CKD that is positively 
associated with arterial atherosclerotic change.25 All these factors lead to decrease kidney function in elderly and explain high prevalence of CKD in elderly as compared to adults among which kidney function remains stable after infancy until late adulthood. 47

Another demographic factor that showed strong association with prevalence of CKD was gender, with CKD being more prevalent among females. The reason for this increase prevalence in females can be explained by two reasons. Firstly, creatinine that is determinant of kidney function (GFR) depends on muscle mass. Females have less muscle mass as compared to males and ultimately less creatinine that explains high prevalence among females because current renal function predictive equations use serum creatinine values to estimate GFR. ${ }^{48}$ Also, these equations include a correction factor for females ( 0.85 for CG \& 0.742 for MDRD). An inaccurate correction factor may also lead to over estimation of prevalence rate among females. Moreover, structure of glomerulus, hormonal balance and metabolic rate of females is different from males. 49

The results of the review showed that the highest prevalence of CKD is estimated to be in Japanese population. Apart from increase in life expectancy, there are various genetic (short stature, low muscle mass, low nephron number, increase survival of CVD patients), environmental (high salt intake, obesity, metabolic syndrome) and social factors (luxury acceptance for dialysis) that put Japanese population at higher risk of CKD and subsequent risk of ESRD. 50

Limitations: Although efforts were made to give an unbiased overview of prevalence of CKD in Asia, but the prevalence rate depicted in this review might be underestimated or overestimated as presence of comorbidities and risk factors were not included in this review. Moreover, biomarkers (proteinuria, albuminuria) for assessing kidney damage were not considered. Due to heterogeneity of data, it was not possible to include all above mentioned factors. We were unable to find studies with mentioned inclusion criteria in many countries of this region such as Sri Lanka, Jordan, Syria, Kuwait and Afghanistan etc. Most of the studies in these countries calculated prevalence of CKD by estimating creatinine clearance via 24-hour urine collection; therefore, such studies were not included.

\section{CONCLUSION}

Currently, both researchers and clinicians are facing challenges in detecting and managing CKD in Asian countries due to limited availability of resources and paucity of health data on national level. Furthermore, disparities in prevalence of CKD owing to different predictive equation further necessitates need of national health registries (NRRs) for early stages of CKD and a uniform criteria to estimate burden of disease. The first and foremost step in addressing this challenge involves development of NRRs for maintaining record of population health data by conducting extensive population-based studied on national level. This would ultimately help to record extent of disease prevalence and would help to control disease by designing and implementing relevant strategies.

\section{REFERENCES}

1. Inke LA, Perrone RD. Assessment of kidney function. Retrieved 2.11.2013; from http://www.uptodate.com/contents/ assessment-of-kidney-function.

2. Tonelli M, Wiebe N, Culleton B, House A, Rabbat C, Fok M, et al. Chronic kidney disease and mortality risk: a systematic review. J Am Soc Nephrol 2006; 17:2034-47.

3. Stevens PE, Levin A. Evaluation and management of chronic kidney disease: synopsis of the kidney disease: improving global outcomes 2012 clinical practice guideline. Ann Int Med 2013; 158:825-30.

4. Go AS, Yang J, Ackerson LM, Lepper K, Robbins S, Massie BM, et al. Hemoglobin level, chronic kidney disease, and the risks of death and hospitalization in adults with chronic heart failure: the anemia in chronic heart failure: Outcomes and resource utilization (ANCHOR) study. Circulation 2006; 113:2713-23.

5. Sarnak MJ, Levey AS, Schoolwerth AC, Coresh J, Culleton B, Hamm LL, et al. Kidney disease as a risk factor for development of cardiovascular disease: A statement from the American heart association councils on kidney in cardiovascular disease, high blood pressure research, clinical cardiology, and epidemiology and prevention. Circulation 2003; 108:2154-69.

6. Kearns B, Gallagher $\mathrm{H}$, de Lusignan S. Predicting the prevalence of chronic kidney disease in the English population: a crosssectional study. BMC Nephrol 2013; 14:49.

7. Coresh J, Selvin E, Stevens LA, Manzi J, Kusek JW, Eggers P, et al. Prevalence of chronic kidney disease in the United States. JAMA 2007; 298:2038-47.

8. Hamer RA, El Nahas AM. The burden of chronic kidney disease: is rising rapidly worldwide. $\mathrm{Br}$ Med $J$ 2006; 332:563.

9. Rigalleau V, Lasseur C, Perlemoine C, Barthe N, Raffaitin C, Liu C, et al. Estimation of glomerular filtration rate in diabetic subjects: Cockcroft formula or modification of diet in renal disease study equation? Diabetes Care 2005; 28:838-43.

10. Michels WM, Grootendorst DC, Verduijn M, Elliott EG, Dekker FW, Krediet RT. Performance of the Cockcroft-Gault, MDRD, and new CKD-EPI formulas in relation to GFR, age, and body size. Clin J Am Soc Nephrol 2010; 5:1003-9.

11. Harmoinen A, Lehtimäki T, Korpela M, Turjanmaa V, Saha $H$. Diagnostic accuracies of plasma creatinine, cystatin $C$, and glomerular filtration rate calculated by the Cockcroft-Gault and Levey (MDRD) formulas. Clin Chem 2003; 49:1223-5.

12. Levey AS, Coresh J, Balk E, Kausz AT, Levin A, Steffes MW, et al. National kidney foundation practice guidelines for chronic kidney disease: evaluation, classification, and stratification. Ann Intern Med 2003; 139:137-47.

13. Singh AK, Farag YM, Mittal BV, Subramanian KK, Reddy SR, Acharya VN, et al. Epidemiology and risk factors of chronic kidney disease in India-results from the SEEK (screening and 
early evaluation of kidney disease) study. BMC Nephrol 2013; 14:114.

14. Ninomiya T, Kiyohara Y, Kubo M, Tanizaki Y, Doi Y, Okubo KE, et al. Chronic kidney disease and cardiovascular disease in a general Japanese population: the Hisayama Study. Kidney Int 2005; 68:228-36.

15. Kang HT, Lee J, Linton JA, Park BJ, Lee YJ. Trends in the prevalence of chronic kidney disease in Korean adults: the Korean national health and nutrition examination survey from 1998 to 2009. Nephrol Dial Transplant 2012; 28:927-36.

16. Hosseinpanah F, Kasraei F, Nassiri AA, Azizi F. High prevalence of chronic kidney disease in Iran: a large population-based study. BMC Public Health 2009; 9:44.

17. Tan T, Gomez L, Bataclan R, Lim M. Risk factors for chronic kidney disease and microalbuminuria in a filipino population: Analysis of the national nutrition and health survey II (NNHES II). ISN World Congress of Nephrology May 31 - June 4, 2013, Hongkong.

18. Hooi LS, Ong LM, Ahmad G, Bavanandan S, Ahmad NA, Naidu BM, et al. A population-based study measuring the prevalence of chronic kidney disease among adults in West Malaysia. Kidney Int 2013; 84:1034-40.

19. Imran S, Shiekh A, Saeed Z, Khan SA, Malik AO, Patel J. Burden of chronic kidney disease in an urban city of Pakistan, a cross-sectional study. J Pak Med Assoc 2015; 65:366-9.

20. Huda MN, Alam KS. Prevalence of chronic kidney disease and its association with risk factors in disadvantageous population. Int J Nephrol 2012; 2012:267329.

21. Varma PP, Raman DK, Ramakrishnan TS, Singh $P$, Varma A. Prevalence of early stages of chronic kidney disease in apparently healthy central government employees in India. Nephrol Dial Transplant 2010; 25:3011-7.

22. Anand S, Khanam MA, Saquib J, Saquib N, Ahmed T, Alam DS, et al. High prevalence of chronic kidney disease in a community survey of urban Bangladeshis: a cross-sectional study. Global Health 2014; 10:9.

23. Jessani S, Bux R, Jafar TH. Prevalence, determinants, and management of chronic kidney disease in Karachi, Pakistan a community-based cross-sectional study. BMC Nephrol 2014; 15:90.

24. Sharma SK, Dhakal S, Thapa L, Ghimire A, Tamrakar R, Chaudhary S, et al. Community-based screening for chronic kidney disease, hypertension and diabetes in Dharan. J Nepal Med Assoc 2013; 52:205-12.

25. Chen J, Wildman RP, Gu D, Kusek JW, Spruill M, Reynolds K, et al. Prevalence of decreased kidney function in Chinese adults aged 35 to 74 years. Kidney Int 2005; 68:2837-45.

26. Li ZY, Xu GB, Xia TA, Wang HY. Prevalence of chronic kidney disease in a middle and old-aged population of Beijing. Clin Chim Acta 2006; 366:209-15.

27. Zhang QL, Rothenbacher D. Prevalence of chronic kidney disease in population-based studies: systematic review. BMC Public Health 2008; 8:117.

28. Konta T, Hao Z, Abiko H, Ishikawa M, Takahashi T, Ikeda A, et al. Prevalence and risk factor analysis of microalbuminuria in Japanese general population: the Takahata study. Kidney Int 2006; 70:751-6.

29. Yi XX, Duo JH, Yang L. Epidemiology investigation of adult chronic kidney disease in the Hulunbeir Prefecture, Inner Mongolia autonomous region. Chin N Nephrol 2010; 26:422-6.

30. Sahin I, Yildirim B, Cetin I, Etikan I, Ozturk B, Ozyurt H, et al. Prevalence of chronic kidney disease in the Black Sea region, Turkey, and investigation of the related factors with chronic kidney disease. Ren Fail 2009; 31:920-7.

31. Alsuwaida AO, Farag YM, Al Sayyari AA, Mousa D, Alhejaili F, Al-Harbi A, et al. Epidemiology of chronic kidney disease in the Kingdom of Saudi Arabia (SEEK-Saudi invnestigators) - a pilot study. Saudi J Kidney Dis Transplant 2010 Nov 1; 21:1066.

32. Perkovic V, Cass A, Patel AA, Suriyawongpaisal P, Barzi F, Chadban $S$, et al. High prevalence of chronic kidney disease in Thailand. Kidney Int 2008; 73:473-9.

33. Domrongkitchaiporn S, Sritara P, Kitiyakara C, Stitchantrakul W, Krittaphol V, Lolekha P, et al. Risk factors for development of decreased kidney function in a southeast Asian population: a 12-year cohort study. J Am Soc Nephrol 2005; 16:791-9.

34. Shankar A, Leng C, Chia KS, Koh D, Tai ES, Saw SM, et al. Association between body mass index and chronic kidney disease in men and women: population-based study of Malay adults in Singapore. Nephrol Dial Transplant 2007; 23:1910-8.

35. Sabanayagam C, Lim SC, Wong TY, Lee J, Shankar A, Tai ES. Ethnic disparities in prevalence and impact of risk factors of chronic kidney disease. Nephrol Dial Transplant 2010; 25: 2564-70.

36. Prodjosudjadi W, Suwitra K, Widiana IG, Loekman JS, Nainggolan G, Prasanto $\mathrm{H}$, e al. Detection and prevention of chronic kidney disease in Indonesia: initial community screening. Nephrology 2009; 14:669-74.

37. Ito J, Dung DT, Vuong MT, Huong NT, Ngoc TB, Ngoc NT, et al. Impact and perspective on chronic kidney disease in an Asian developing country: A large-scale survey in North Vietnam. Nephron Clin Pract 2008; 109:c25-32.

38. Lamb EJ, Tomson CR, Roderick PJ. Estimating kidney function in adults using formulae. Ann Clin Biochem 2005; 42:321-45.

39. Froissart M, Rossert J, Jacquot C, Paillard M, Houillier P. Predictive performance of the modification of diet in renal disease and Cockcroft-Gault equations for estimating renal function. J Am Soc Nephrol 2005; 16:763-73.

40. Coresh J, Byrd-Holt D, Astor BC, Briggs JP, Eggers PW, Lacher DA, et al. Chronic kidney disease awareness, prevalence, and trends among US adults, 1999 to 2000. J Am Soc Nephrol 2005; 16:180-8.

41. Garg AX, Papaioannou A, Ferko N, Campbell G, Clarke JA, Ray JG. Estimating the prevalence of renal insufficiency in seniors requiring long-term care. Kidney Int 2004; 65:649-53.

42. O'Hare AM, Choi Al, Bertenthal D, Bacchetti P, Garg AX, Kaufman JS, et al. Age affects outcomes in chronic kidney disease. J Am Soc Nephrol 2007; 18:2758-65.

43. Eriksen BO, Ingebretsen OC. The progression of chronic kidney disease: a 10-year population-based study of the effects of gender and age. Kidney Int 2006; 69:375-82.

44. Raymond NT, Zehnder D, Smith SC, Stinson JA, Lehnert H, Higgins RM. Elevated relative mortality risk with mild-tomoderate chronic kidney disease decreases with age. Nephrol Dial Transplant 2007; 22:3214-20.

45. Berg UB. Differences in decline in GFR with age between males and females. Reference data on clearances of inulin and PAH in potential kidney donors. Nephrol Dial Transplant 2006; 21:2577-82. 
46. Snively CS, Gutierrez C. Chronic kidney disease: prevention and treatment of common complications. Am Fam Physician 2004; 70:1921-8.

47. Lamb EJ, O'Riordan SE, Delaney MP. Kidney function in older people: pathology, assessment and management. Clin Chim Acta 2003; 334:25-40.

48. Janssen I, Heymsfield SB, Wang Z, Ross R. Skeletal muscle mass and distribution in 468 men and women aged $18-88$ years. J Appl Physiol 2000; 89:81-8.

49. Neugarten J, Acharya A, Silbiger SR. Effect of gender on the progression of nondiabetic renal disease a meta-analysis. J Am Soc Nephrol 2000; 11:319-29.

50. Iseki K. Chronic kidney disease in Japan. Intern Med 2008; 47: 681-9.

…绳... 